\title{
Effect of Elephant Grass Genotypes to Bioenergy Production
}

\author{
Henrique Guimarães de Favare ${ }^{1}$, Joadil Gonçalves de Abreu ${ }^{1}$, \\ Livia Vieira de Barros ${ }^{1}$, Felipe Gomes da Silva ${ }^{1}$, Luis Miguel Mendes Ferreira ${ }^{2}$, \\ Marco Antônio Aparecido Barelli ${ }^{3}$, Inácio Martins da Silva Neto ${ }^{4}$, \\ Carlos Eduardo Avelino Cabral ${ }^{1}$, Wender Mateus Peixoto ${ }^{1 *}$, \\ Francisco Ildefonso da Silva Campos ${ }^{5}$, Francisco José da Silva Ledo ${ }^{6}$, \\ Vanessa Quitete Ribeiro da Silva ${ }^{7}$ and Larah Drielly Santos Herrera ${ }^{1}$ \\ ${ }^{1}$ Federal University of Mato Grosso, Cuiabá, Brazil. \\ ${ }^{2}$ University of Trás-os-Montes e Alto Douro, Vila Real, Portugal. \\ ${ }^{3}$ University of the State of Mato Grosso, Cáceres, Brazil. \\ ${ }^{4}$ University Center of Várzea Grande, Várzea Grande, Brazil. \\ ${ }^{5}$ Company of Research, Assistance and Rural Extension of Mato Grosso, Várzea Grande, Brazil. \\ ${ }^{6}$ Brazilian Agricultural Research Corporation, Juiz de Fora (MG), Brazil. \\ ${ }^{7}$ Brazilian Agricultural Research Corporation, Sinop (MT), Brazil.
}

\section{Authors' contributions}

This work was carried out in collaboration between all authors. The authors FISC, FJSD and VQRS designed and wrote the protocol for the experiment. The authors HGF, JGA and MAAB conducted the experiment and wrote the first draft of the manuscript. The authors LVB, FGS, LMMF, IMSN, CEAC, WMP and LDSH discussed the results, corrected and improved the writing of the manuscript in English version. All authors read and approved the final manuscript.

Article Information

DOI: 10.9734/JEAI/2019/v38i130289

Editor(s):

(1) Dr. Luis F. Goulao, Professor, Tropical Research Institute - IICT, Agri4Safe / BioTrop: Polo Mendes Hand, Agro-Industries and Tropical Agriculture Pavilion ( $3^{\text {rd }}$ Floor), Portugal. Reviewers:

(1) Alok Nahata, Ying Zhi Agricultural and Industries Sdn Bhd, Malaysia. (2) Akhator, E. Peter, University of Benin, Nigeria. (3) Nataliia Kutsokon, Institute of Cell Biology and Genetic Engineering NAS of Ukraine, Ukrane. (4) Akinyemi Bosede Kemi, Benue State University, Nigeria. Complete Peer review History: http://www.sdiarticle3.com/review-history/49640 


\section{ABSTRACT}

The study aimed to evaluate the agronomic characteristics of elephant grass (Pennisetum purpureum Schum.) genotypes on energy production in the combustion form. A randomized block design with 3 repetitions was used. The treatments were arranged in subdivided plots scheme, considering as a plot the genotypes and as subplots, the harvest season. The agronomic characteristics plant height $(\mathrm{H})$, leaf length (LL), leaf blade width (LBW), stem diameter (SD), tillers number (TN), stem percentage (SP), dry matter yield (DMY) were evaluated. The rainy season provided greater $\mathrm{H}$ to elephant grass genotypes with height above $3.5 \mathrm{~m}$. The average SP obtained by the genotypes was $68.21 \%$ and $67.21 \%$ to the first and second year of cultivation, respectively, which gives the biomass good quality of burning. The rainy season provided greater DMY comparing to the dry season. In the first year of cultivation there were genotypes with annual dry matter yield (ADMY) above 50 ton ha $^{-1}$ year $^{-1}$, however, the non-maintenance of soil fertility promoted the reduction of $39.17 \%$ and $39.05 \%$ in the DMY and ADMY, respectively. Analyzing the agronomic characteristics, we conclude that the promising genotypes of elephant grass to produce energy in the form of direct combustion are CNPGL 91-25-1, Cubano Pinda, BRS Canará, Porto Rico and Mercker.

Keywords: Bioenergy; biomass; Pennisetum purpureum; stem percentage; yield.

\section{INTRODUCTION}

Fossil fuels present environmental problems that alter the climate dynamics, as well as being a finite resource. Therefore, there is a need to generate alternative energy, from renewable natural resources, to the point of meeting the needs of society, with minimal environmental impact.

Energy crops have been environmentally more sustainable alternatives to the intensive use of fossil fuels because the biomass produced can be used in several energy segments, for example, biofuel, electric energy and thermal energy. In the greenhouse gas (GHG) mitigation plan, these plants stand out from the fossil fuels for not emitting oxides to the environment responsible for the acid rains [1], low cost of production with minimal use of fossil fuel sources, high potential for carbon sequestration, once the emitted $\mathrm{CO}_{2}$ is absorbed again during photosynthesis [2]. These characteristics have resulted in interest from both the private and public sectors, not only because of its economic applicability but also mainly because of the goals and agreements stipulated in the Rio 21, Kyoto Protocol and Paris Agreement [3].

There are promising species for energy use in the agricultural sector, among them elephant grass (Pennisetum purpureum Schum.), one of the most widespread tropical forage species in the world, used on livestock properties as a roughage [4]. Included among energy crops, it can be the most important renewable source for future energy production [5], due to its versatility such as fiber for paper industry [6]; biomass for the production of bioethanol [7]; direct combustion of biomass as a substitute for charcoal $[8,9]$; co-products generated in biorefineries [10,2]. In addition, it presents excellent energy balance elucidated by [11] in the use of in-kind burning of elephant grass, obtaining 21.3 units of renewable energy for each unit of fossil energy used in the production process.

In Brazil, traditionally, eucalyptus and its coproducts are widely used as an energy resource. In this sense, elephant grass appears as an option because it presents dry matter yields above 50 ton ha $^{-1}$ year $^{-1}$ [12], approximately double the eucalyptus; lower production cycle with semiannual harvest; C4 metabolism that ensures greater carbon assimilation; calorific power between 4,100 and 4,500 kcal kg ${ }^{-1}$ [13]; low production cost and the possibility of producing briquettes and pellets [14].

The variability of elephant grass genotypes is large and well under subtropical and tropical conditions in Brazil. Recently the Brazilian Agricultural Research Corporation (Embrapa) released to the Atlantic Forest biome, the cultivar BRS Capiaçu to forage purposes [15], but with potential to energy production, it has produced more than 80 ton $^{-1}$ year $^{-1}$ with two semiannual harvests [16]. On the other hand, there are cultivars that are in disuse and can be promising for direct burning, due to the high contents of dry matter and fiber that present [17]. 
Since the elephant grass is among the most relevant crops as a renewable source for energy production in the coming decades, this study aimed to evaluate the agronomic characteristics of elephant grass genotypes on the energy production in the combustion form.

\section{MATERIALS AND METHODS}

The experiment was carried out at the Experimental Field of the Empresa Matogrossense de Pesquisa, Assistência e Extensão Rural (EMPAER) in Cáceres - MT, Brazil, located at $16^{\circ} 09^{\prime} 04^{\prime \prime}$ of Latitude South; $57^{\circ} 38^{\prime} 03^{\prime \prime}$ West Longitude; altitude of $157 \mathrm{~m}$. The climate in the municipality, according to the Köppen classification, is Aw type, that is, tropical, metamérmico climate, characterized by two well defined periods: Dry (May to September) and rainy (October to April).

The experiment lasted two years (from 2016 to 2018), with harvests every 6 months counted after the standardization harvest (March 2016), being made one harvest in the dry season (September) and another one in the rainy season (March), in four harvests in two consecutive years.

Chemical and granulometric analysis of the soil of experimental area was carried out as shown in Table 1 prior to planting where the establishment fertilization recommendation was made. After the last harvest of the elephant grass, a new analysis of the soil was made to verify the level of fertility of the soil after the four harvest cycles. The soil was characterized as Chernosolic Eutrophic Red-Yellow ARGISSOLO, medium/clayey texture.

Soil preparation was done with a plowing and two harrowing in the month of September 2015, without application of limestone, due to the percentage of saturation per desired base being above 50\%, considered adequate for establishment of elephant grass [18]. The elephant grass seedlings were obtained in the nursery of the Experimental Field of the EMPAER. The planting of the stems was done in a "foot-with-tip" system, with the seedlings placed in the planting groove and covered with soil, using a spacing of $1.0 \mathrm{~m}$ between rows.

The single fertilization was carried out in the establishment of elephant grass in the amounts of $70 \mathrm{~kg}$ of $\mathrm{P}_{2} \mathrm{O}_{5} \mathrm{ha}^{-1}, 100 \mathrm{~kg}$ of $\mathrm{K}_{2} \mathrm{O}$ ha ${ }^{-1}$ and 100 $\mathrm{kg}$ of $\mathrm{N} \mathrm{ha}^{-1}$ using the following fertilizers: simple superphosphate, potassium chloride and ammonium sulfate, respectively. Both nitrogen and potassium fertilizer were divided in two applications, the first one in planting (November 2015), and the second one shortly after the harvest to uniformity (March 2016).

The experimental design was a randomized block with three repetitions. The treatments were arranged in subdivided plots scheme, considering as genotypes (Cubano Pinda, Porto Rico, Vrukwona, Piracicaba 241, Cuba 116, Taiwan A 25, Mercker, Napier, Canará, Guaçu, Cameroon and the CNPGL 93-41-1 and CNPGL 91-25-1 clones) and harvest season (dry and rainy) as subplots. The experimental unit consisted of four rows of $5.0 \mathrm{~m}$ in length with spacing between rows of $1.0 \mathrm{~m}$, totaling $20 \mathrm{~m}^{2}$. The two central rows were considered as useful area, scoring $1.0 \mathrm{~m}$ at the ends.

The first harvest was made in September 2016 (dry harvest), and successive harvests were carried out every 6 months, as follows: March 2017 (rainy harvest), September 2017 (dry harvest); March 2018 (rainy harvest).

The agronomic characteristics evaluated were obtained by the arithmetic mean of three tillers selected at random within the useful area. They were: plant height $-H(m)$, stem diameter - SD $(\mathrm{mm})$, leaf length - LL $(\mathrm{m})$, leaf blade width LBW $(\mathrm{cm})$, tillers number per linear meter - TN (linear $\mathrm{m}$ ), dry matter yield per season - DMY $\left(\right.$ ton $\mathrm{ha}^{-1}$ ) and annual dry matter yield - ADMY $\left(\right.$ ton ha $\left.{ }^{-1}\right)$.

Table 1. Chemical and granulometric analysis in the 0 to $20 \mathrm{~cm}$ layer of the experimental area before planting $(A)$ and after the last cut of the elephant grass (B)

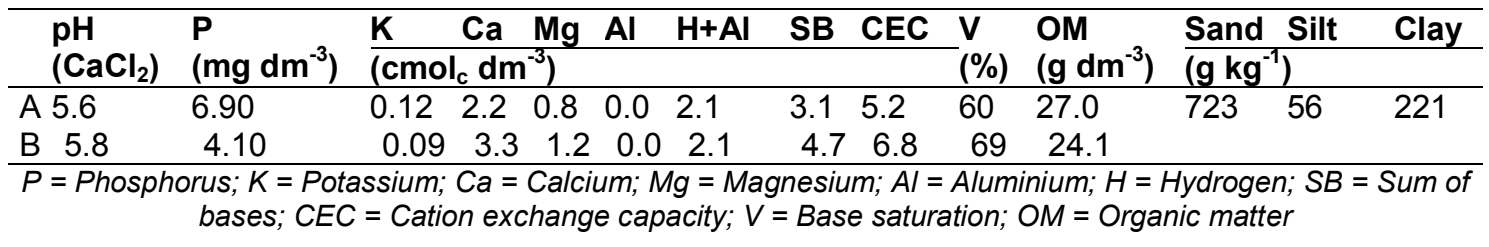


The dry matter content - DM\% and stem percentage - SP\% were obtained from three tillers selected at random within the useful area and represented the whole plant, leaf blade and pseudostem. These portions were duly separated into the morphological components, then minced and packed in a paper bag, weighed and placed in an oven of $55^{\circ} \mathrm{C}$ until reaching a constant mass. Afterwards, the samples were again weighed to obtain the air-dried sample.

The data collected were submitted to Lilliefors test for normality and Bartlett's test for homogeneity of variances. We proceeded with analysis of variance and Scott-Knott's test [19].

\section{RESULTS AND DISCUSSION}

\subsection{Plant Height, Leaf Length, Leaf Blade Width and Stem Percentage}

In the first year of cultivation, comparing both seasons (rainy and dry), all genotypes had higher $\mathrm{H}(\mathrm{P}<.05)$ in the rainy. However, the CNPGL 93-41-1 clone did not differ statistically from the dry season (Table 2), which shows that the moisture factor did not affect it with a decrease in $\mathrm{H}$.

The $\mathrm{H}$ of genotypes in the dry season, there was no difference $(P>.05)$ with an average of 2.56 $\mathrm{m}$. Otherwise, the genotypes Cameroon, Porto Rico, Taiwan A 25, Vrukwona, Guaçu, Cuba 116,
BRS Canará and Cubano Pinda had the highest $H(P<.05)$ in the rainy season.

In the second year of cultivation, CNPGL 93-41-1 presented a similar result to the other genotypes, obtaining greater $\mathrm{H}$ in the rainy season (Table 3 ). The $\mathrm{H}$ reduction in the dry season is due to the lack of rainfall, which restricts plant growth, occurring naturally at this time of year. With the return of rainfall, plant height increases were observed for all genotypes, thus demonstrating the direct relationship between soil water availability and elephant grass height [20].

The genotypes that presented, at the same time, greater $\mathrm{H}(\mathrm{P}<.05)$ in the dry and rainy seasons in the $2^{\text {nd }}$ year of cultivation were Taiwan A-25, Piracicaba 241, Cubano Pinda and BRS Canará with heights between 3.79 and $4.24 \mathrm{~m}$. [16] evaluating semiannual harvests in elephant grass genotypes (BRS Capiaçu, Venezuela and Madeira), biomass sorghum (BRS 716) and sugarcane (RB 92579 and cane energy) verified plant height varying from 2.9 to $3.4 \mathrm{~m}$ among the evaluated species/cultivars, with emphasis on elephant grass that presented the superior heights. It is worth noting that elephant grass has the potential to reach more than $5.0 \mathrm{~m}$ in height, which makes this feature extremely important for energetic purpose of elephant grass, as it positively correlates with dry matter yield [21].

Table 2. Plant height (H), Leaf Length (LL), Leaf Blade Width (LBW) and Stem Percentage (SP) of elephant grass genotypes, at 6 months of age in the dry and rainy seasons of the first year of cultivation (2016-2017)

\begin{tabular}{|c|c|c|c|c|c|c|c|c|}
\hline \multirow[t]{2}{*}{ Genotype } & \multicolumn{2}{|c|}{$H(m)$} & \multicolumn{2}{|c|}{ LL (m) } & \multicolumn{2}{|c|}{ LBW (cm) } & \multicolumn{2}{|c|}{ SP (\%) } \\
\hline & Dry & Rainy & Dry & Rainy & Dry & Rainy & Dry & Rainy \\
\hline CNPGL 93-41-1 & $2.93 a A$ & $2.79 \mathrm{bA}$ & $1.33 a \mathrm{~A}$ & $1.01 \mathrm{aA}$ & $5.37 a A$ & $4.67 a B$ & $60.61 \mathrm{aA}$ & $68.48 a A$ \\
\hline CNPGL 91-25-1 & $2.41 \mathrm{aB}$ & $2.94 \mathrm{bA}$ & $1.31 \mathrm{aA}$ & $1.16 a A$ & $4.70 \mathrm{bA}$ & $4.35 \mathrm{bA}$ & $64.98 \mathrm{aA}$ & $69.06 \mathrm{aA}$ \\
\hline Taiwan A25 & $2.72 \mathrm{aB}$ & $3.35 a A$ & $0.78 \mathrm{bA}$ & $0.83 a A$ & $1.23 \mathrm{eB}$ & $3.06 \mathrm{cA}$ & $63.90 \mathrm{aA}$ & $66.30 \mathrm{aA}$ \\
\hline Cuba 116 & $2.67 a B$ & $3.41 \mathrm{aA}$ & $1.11 \mathrm{aA}$ & $0.88 a A$ & $3.74 \mathrm{bA}$ & $3.08 \mathrm{cA}$ & $70.56 a A$ & $66.70 \mathrm{aA}$ \\
\hline Mercker & $2.39 \mathrm{aB}$ & $3.11 \mathrm{bA}$ & $1.27 a A$ & $1.01 \mathrm{aA}$ & $5.07 \mathrm{aA}$ & 5.09aA & $66.25 a A$ & $65.00 \mathrm{aA}$ \\
\hline Cameroon & $2.47 a B$ & $3.30 \mathrm{aA}$ & $1.20 \mathrm{aA}$ & $1.07 \mathrm{aA}$ & $4.37 \mathrm{bA}$ & $4.58 \mathrm{aA}$ & $66.48 \mathrm{aA}$ & $62.63 a A$ \\
\hline Piracicaba 241 & $2.26 a B$ & $3.11 \mathrm{bA}$ & $1.38 \mathrm{aA}$ & $1.04 \mathrm{aB}$ & $5.03 a A$ & $3.99 b B$ & $72.62 \mathrm{aA}$ & $66.13 a A$ \\
\hline Vrukwona & $2.24 \mathrm{aB}$ & 3.36aA & $1.24 \mathrm{aA}$ & $0.92 \mathrm{aA}$ & $4.13 \mathrm{bA}$ & $4.08 \mathrm{bA}$ & 69.92aA & $65.50 a A$ \\
\hline Napier & $2.50 \mathrm{aB}$ & $3.02 \mathrm{bA}$ & $1.22 \mathrm{aA}$ & $0.96 a A$ & $3.93 \mathrm{bA}$ & $3.69 \mathrm{cA}$ & 71.60aA & $70.80 a A$ \\
\hline Porto Rico & $2.67 \mathrm{aB}$ & $3.35 a A$ & $0.73 \mathrm{bA}$ & $0.99 \mathrm{aA}$ & $2.30 \mathrm{~dB}$ & $3.12 \mathrm{cA}$ & $70.17 a A$ & $63.20 \mathrm{aA}$ \\
\hline Guaçu & $2.85 a B$ & $3.38 \mathrm{aA}$ & 1.09aA & $0.95 a A$ & $3.17 \mathrm{cB}$ & $4.02 \mathrm{bA}$ & 75.07aA & 69.70aA \\
\hline Cubano Pinda & $2.58 \mathrm{aB}$ & $3.57 a A$ & $1.08 \mathrm{aA}$ & $1.04 \mathrm{aA}$ & $3.60 \mathrm{bB}$ & $4.33 \mathrm{bA}$ & $72.48 a A$ & $70.26 a A$ \\
\hline BRS Canará & $2.55 a B$ & $3.47 a \mathrm{~A}$ & $1.35 a A$ & $1.01 \mathrm{aB}$ & $3.77 \mathrm{bA}$ & $4.14 \mathrm{bA}$ & 75.39aA & $70.80 a A$ \\
\hline CV (a) (\%) & 10.40 & & 15.58 & & 11.78 & & 9.15 & \\
\hline CV (b) (\%) & 8.80 & & 17.77 & & 10.04 & & 11.62 & \\
\hline
\end{tabular}

by the same letter, lowercase vertical and uppercase horizontal do not differ from each other by the Scott Knott test at $5 \%$ 
Table 3. Plant height (H), leaf length (LL), Leaf Blade Width (LBW) and stem percentage (SP) of elephant grass genotypes, at 6 months of age in the dry and rainy seasons of the first year of cultivation (2017-2018)

\begin{tabular}{|c|c|c|c|c|c|c|c|c|}
\hline \multirow[t]{2}{*}{ Genotype } & \multicolumn{2}{|c|}{$H(m)$} & \multicolumn{2}{|c|}{ LL (m) } & \multicolumn{2}{|c|}{ LBW (cm) } & \multicolumn{2}{|c|}{ SP (\%) } \\
\hline & Dry & Rainy & Dry & Rainy & Dry & Rainy & Dry & Rainy \\
\hline CNPGL 93-41-1 & $1.47 \mathrm{bB}$ & $2.58 \mathrm{cA}$ & $0.87 a A$ & $0.99 \mathrm{aA}$ & $4.07 a \mathrm{~A}$ & $4.90 a \mathrm{~A}$ & $56.97 \mathrm{aA}$ & 69.39aA \\
\hline CNPGL $91-25-1$ & $1.55 \mathrm{bB}$ & $3.95 \mathrm{aA}$ & $0.79 a A$ & $0.22 \mathrm{cB}$ & $3.82 \mathrm{aA}$ & $1.67 \mathrm{bB}$ & $63.89 a A$ & 74.09Aa \\
\hline Taiwan A25 & $1.84 \mathrm{aB}$ & $4.31 \mathrm{aA}$ & $0.75 a A$ & $0.22 \mathrm{cB}$ & $1.59 \mathrm{bA}$ & $1.17 \mathrm{bA}$ & 73.52aA & 68.72aA \\
\hline Cuba 116 & $1.91 \mathrm{aB}$ & $3.50 \mathrm{bA}$ & $0.75 \mathrm{aA}$ & $0.54 \mathrm{bA}$ & $3.21 \mathrm{aA}$ & $2.50 \mathrm{bA}$ & $69.46 \mathrm{aA}$ & 77.10aA \\
\hline & $52 \mathrm{bB}$ & $3.47 \mathrm{bA}$ & $0.83 a \mathrm{~A}$ & $0.63 \mathrm{bA}$ & $4.09 \mathrm{aA}$ & & $58.29 \mathrm{aA}$ & $73.75 \mathrm{aA}$ \\
\hline Cameroon & $1.88 \mathrm{aB}$ & $3.48 \mathrm{bA}$ & $0.87 a A$ & $0.93 a A$ & $3.88 \mathrm{aA}$ & $4.23 \mathrm{aA}$ & $70.53 \mathrm{aA}$ & 77.08aA \\
\hline ba 241 & 1.88aB & $3.79 \mathrm{aA}$ & $0.82 \mathrm{aA}$ & $0.40 \mathrm{cB}$ & $3.20 \mathrm{aA}$ & $\mathrm{aA}$ & $66.96 \mathrm{aA}$ & 64.01aA \\
\hline & $1 \mathrm{aB}$ & $3.27 \mathrm{bA}$ & $0.78 \mathrm{aA}$ & $0.70 \mathrm{bA}$ & $3.54 \mathrm{aA}$ & & $69.60 \mathrm{aA}$ & $68.08 \mathrm{aA}$ \\
\hline Napier & $1.52 \mathrm{bB}$ & $3.04 \mathrm{bA}$ & $0.81 \mathrm{aA}$ & $0.92 \mathrm{aA}$ & $3.02 \mathrm{aA}$ & $3.50 \mathrm{aA}$ & $60.96 \mathrm{aA}$ & 46.17aA \\
\hline Porto Rico & $2.11 \mathrm{aB}$ & $3.36 \mathrm{bA}$ & $0.84 a A$ & $0.67 \mathrm{bA}$ & $1.71 \mathrm{bA}$ & $2.67 \mathrm{bA}$ & $67.49 \mathrm{aA}$ & $54.39 \mathrm{aA}$ \\
\hline & $15 \mathrm{aB}$ & $3.27 \mathrm{bA}$ & $0.74 \mathrm{aA}$ & $0.64 \mathrm{bA}$ & $2.13 \mathrm{bA}$ & & 74.79aA & $63.48 \mathrm{aA}$ \\
\hline$a$ & $1.96 \mathrm{aB}$ & $4.12 \mathrm{aA}$ & $0.85 a A$ & $0.25 \mathrm{cB}$ & $2.13 \mathrm{bA}$ & 1.6 & $73.45 \mathrm{aA}$ & 73.61aA \\
\hline BRS Canará & $2.06 \mathrm{aB}$ & $4.24 \mathrm{aA}$ & $0.84 a A$ & $0.29 \mathrm{cB}$ & $3.04 \mathrm{aA}$ & $1.90 \mathrm{bA}$ & $67.13 \mathrm{aA}$ & $67.56 \mathrm{aA}$ \\
\hline$\overline{C V}(\mathrm{a})(\%)$ & 18.12 & & 21.96 & & 25.01 & & 13.72 & \\
\hline $\mathrm{CV}(\mathrm{b})(\%)$ & 11.35 & & 24.38 & & 24.62 & & 15.16 & \\
\hline
\end{tabular}

CV (a) (\%): Coefficient of variation of plot; CV (b) (\%): Coefficient of variation of the subplot; Averages followed by the same letter, lowercase vertical and uppercase horizontal do not differ from each other by the Scott Knott test at $5 \%$

In the first year of cultivation, comparing both seasons, all genotypes presented lower LL in the dry season $(P<.05)$, except for Piracicaba 241 and BRS Canará genotypes (Table 2). During the dry season, there was a significant difference between the genotypes $(P<.05)$ where only Porto Rico and Taiwan A 25 had lower LL, respectively, with 0.73 and $0.78 \mathrm{~m}$. There was no significant difference between genotypes in the rainy season, with average $L L$ of $1.07 \mathrm{~m}$.

In the second year of cultivation, there was a statistical difference between both seasons, being that the CNPGL 91-25-1, Taiwan A 25, Piracicaba 241, Cubano Pinda and BRS Canará genotpes had the lowest LL in the rainy season $(P<.05)$ (Table 3). In the dry season, there was no difference between genotypes, with average LL of $0.81 \mathrm{~m}$.

The leaf blade is responsible for the photosynthesis and fixation of free carbon in the plant structure, but this can change the chemical characteristics of the biomass because there is a higher deposition of minerals compared to the more fibrous fraction coming from the stem [22]. This is undesirable due to the formation of chemical compounds that at high temperature damage the metallic surfaces of the boilers and increase the deposition of ashes [23].

As a strategy for the reduction of post-burning residues and better quality of biomass, the productive cycle of the energy crop is very important because gains are obtained as increased dry matter yield and percentage of fibers and reduction of minerals. [24], evaluating the yield of elephant grass BRS Canará to hay production at harvest intervals of $42,60,76,91$ and 105 days in the rainy season, verified an increase in dry matter yield and reduction in mineral matter, according to the increase in age, which consequently will have a direct influence on the calorific value of the biomass.

To LBW in the first year of cultivation, comparing both seasons, all genotypes had higher LBW in the rainy season $(P<.05)$, except for CNPGL 93-41-1 and Piracicaba 241 genotypes which obtained respectively 4.67 and $3.99 \mathrm{~cm}$ (Table 2). When observed within each season, the CNPGL 93-41-1 clone and the Mercker genotype obtained higher LBW within the dry season near to Piracicaba 241 , as in the rainy season, near to the Cameron.

In the $2^{\text {nd }}$ year of cultivation, comparing the seasons, just CNPGL 91-25-1 genotype presented superior LBW $(P<.05)$ in the dry season than the others (Table 3 ). In the dry season, there was a significant difference with superior LBW for most genotypes $(P<.05)$, excepting Taiwan A 25, Porto Rico, Guaçu, Cubano Pinda with respective values of 1.59 ; $1.71 ; 2.13 ; 2.13 \mathrm{~cm}$. In the rainy seasons the superior LBW $(P<.05)$ was obtained by CNPGL 
93-41-1, Mercker, Cameroon, Piracicaba 241, Vrucwona, Napier and Guaçu genotypes.

In breeding programs for biomass production, genotypes with higher LBW have a negative correlation with dry matter production $(r=-0.81)$, in contrast, increases in variables such as $\mathrm{H}, \mathrm{SD}$ and TN, the lower the LBW and thus higher DMY values will be obtained, according to [21]. Decrease in DM yield of elephant grass due to the presence of leaf blade is probably due to the lower density of this fraction, especially when compared with the stem. "Lighter" morphological structures are undesirable in direct burning due to the correlations between their elemental components (carbon, hydrogen, oxygen) and the quality of thermal energy [25]. In addition, the stem/leaf ratio has a direct influence on the biomass calorific value, which is generally higher in the stems [8]. Therefore, genotypes with lower leaf area (length and width) can present biomass with better quality of burning.

To SP there was no significant difference $(P>$ .05) between seasons and genotypes, independent of the years of cultivation, and the average obtained was $68.21 \%$ and $67.21 \%$ to the first and second year of cultivation, respectively (Tables 2 and 3). [26], studying agronomic traits and elephant grass biomass from nitrogen doses, also did not find differences $(P>$.05) between the genotypes and the doses studied, and SP ranged from 60 to $70 \%$.

The high stem percentage in elephant grass results in a higher stem/leaf ratio, and this reflects directly on biomass quality. [8], when making the characterization of the different parts of the elephant grass to the production of biofuels, verified a difference between the stem and leaf blade fraction, being ashes 1.75 and $4.0 \%$, respectively; calorific power 18.11 and $16.21 \mathrm{MJkg}^{-1}$; nitrogen 0.99 and $1.01 \%$; sulfur 1.47 and $1.75 \%$. The stem of the elephant grass is structured in a fibrous, harder part, which forms the bark and marrow with vascular bundles rich in fibers. Its morphological structure is similar to sugarcane bagasse [27], which is already widely used as a source of energy in the form of combustion in the sugar and alcohol industry.

\subsection{Stem Diameter, Tillers Number, Dry Matter Yield and Annual Dry Matter Yield}

According to $[26,28]$ the $S D$ is of great importance in the selection of genotypes, since it is directly related to the dry matter yield besides biomass quality. Higher SD results in higher content of lignocellulosic compounds in the cell

Table 4. Annual Dry Matter Yield (ADMY) and by season (DMY), Stem Diameter (SD) and Tillers Number (TN) of elephant grass genotypes at 6 months of age in the dry and rainy seasons of the first year of cultivation (2016-2017)

\begin{tabular}{|c|c|c|c|c|c|c|c|}
\hline \multirow[t]{2}{*}{ Genotype } & \multicolumn{2}{|c|}{ SD (mm) } & \multicolumn{2}{|c|}{ TN (linear $\mathrm{m}$ ) } & \multicolumn{2}{|c|}{ DMY (ton ha-1) } & \multirow{2}{*}{$\begin{array}{l}\text { ADMY } \\
\left(\text { ton ha }^{-1} \text { year }^{-1} \text { ) }\right.\end{array}$} \\
\hline & Dry & Rainy & Dry & Rainy & Dry & Rainy & \\
\hline CNPGL 93-41-1 & $17.33 \mathrm{aA}$ & $16.08 \mathrm{bA}$ & $14.61 \mathrm{bA}$ & $14.11 \mathrm{aA}$ & $16.71 \mathrm{aA}$ & $22.81 \mathrm{bA}$ & $39.52 b$ \\
\hline CNPGL 91-25-1 & 18.33aA & $15.08 \mathrm{bB}$ & $18.67 \mathrm{bA}$ & $20.00 a A$ & $25.98 A$ & $31.43 a A$ & $57.41 \mathrm{a}$ \\
\hline Taiwan A25 & $12.00 \mathrm{bA}$ & $14.25 \mathrm{bA}$ & $22.94 a A$ & $19.00 \mathrm{aA}$ & $16.87 \mathrm{aA}$ & $24.30 \mathrm{bA}$ & $41.18 b$ \\
\hline Cuba 116 & $13.00 \mathrm{bB}$ & $16.42 \mathrm{bA}$ & $17.72 \mathrm{bA}$ & $20.33 a A$ & $15.57 \mathrm{aB}$ & $31.72 \mathrm{aA}$ & $47.30 \mathrm{~b}$ \\
\hline Mercker & 16.67aA & $16.08 \mathrm{bA}$ & $16.83 \mathrm{bA}$ & 16.17aA & $25.79 a A$ & $32.48 a A$ & $58.27 a$ \\
\hline Cameroon & $15.00 \mathrm{bA}$ & $16.50 \mathrm{bA}$ & $17.22 \mathrm{bA}$ & $18.06 \mathrm{aA}$ & $22.19 a A$ & $25.68 \mathrm{bA}$ & $47.87 b$ \\
\hline Piracicaba 241 & 17.67aA & 13.30bB & $14.78 \mathrm{bA}$ & $14.22 \mathrm{aA}$ & $16.91 \mathrm{aA}$ & $23.28 \mathrm{bA}$ & $40.20 b$ \\
\hline Vrukwona & $14.00 \mathrm{bA}$ & $14.17 \mathrm{bA}$ & $18.78 \mathrm{bA}$ & $16.83 a A$ & $19.48 \mathrm{aA}$ & $26.82 \mathrm{bA}$ & $46.30 \mathrm{~b}$ \\
\hline Napier & $14.00 \mathrm{bA}$ & $15.00 \mathrm{bA}$ & $20.11 \mathrm{bA}$ & $17.11 \mathrm{aA}$ & $24.50 \mathrm{aA}$ & $21.64 \mathrm{bA}$ & $46.14 b$ \\
\hline Porto Rico & $14.67 \mathrm{bA}$ & $13.17 \mathrm{bA}$ & $26.72 a A$ & $20.94 a A$ & $22.50 \mathrm{aB}$ & $34.26 \mathrm{aA}$ & $58.76 a$ \\
\hline Guaçu & $13.33 \mathrm{bA}$ & $15.33 \mathrm{bA}$ & $18.72 \mathrm{bA}$ & $15.72 \mathrm{aA}$ & $17.89 a A$ & $25.98 \mathrm{bA}$ & $43.88 b$ \\
\hline Cubano Pinda & $13.00 \mathrm{bB}$ & $20.58 a A$ & $17.72 \mathrm{bA}$ & $14.50 \mathrm{aA}$ & $18.82 \mathrm{aB}$ & $33.32 \mathrm{aA}$ & $52.15 a$ \\
\hline BRS Canará & $13.00 \mathrm{bA}$ & $14.83 \mathrm{bA}$ & $18.17 \mathrm{bA}$ & 16.33aA & $24.79 a A$ & $34.78 \mathrm{aA}$ & $59.58 a$ \\
\hline $\mathrm{CV}(\mathrm{a})(\%)$ & 12.39 & & 25.48 & & 30.61 & & 26.89 \\
\hline CV (b) (\%) & 11.09 & & 19.34 & & 24.58 & & 16.33 \\
\hline
\end{tabular}


Table 5. Annual Dry Matter Yield (ADMY) and by season (DMY), Stem Diameter (SD) and Tillers Number (TN) of elephant grass genotypes at 6 months of age in the dry and rainy seasons of the first year of cultivation (2017-2018)

\begin{tabular}{|c|c|c|c|c|c|c|c|}
\hline \multirow[t]{2}{*}{ Genotype } & \multicolumn{2}{|c|}{ SD (mm) } & \multicolumn{2}{|c|}{ TN (linear m) } & \multicolumn{2}{|c|}{ DMY (ton ha ${ }^{-1}$ ) } & \multirow{2}{*}{$\begin{array}{l}\text { ADMY } \\
\left(\text { ton }^{-1} \text { year }^{-1}\right)\end{array}$} \\
\hline & Dry & Rainy & Dry & Rainy & Dry & Rainy & \\
\hline$\overline{C N P G L}$ 93-41-1 & $15.56 \mathrm{aB}$ & $22.33 a A$ & $19.61 \mathrm{cA}$ & $16.83 \mathrm{bA}$ & 13.08aA & $15.19 \mathrm{aA}$ & $28.28 a$ \\
\hline CNPGL 91-25-1 & $14.22 \mathrm{aB}$ & $21.33 a A$ & $20.56 \mathrm{bA}$ & $18.94 a A$ & 14.39aA & $14.65 \mathrm{aA}$ & $29.04 a$ \\
\hline Taiwan A25 & $9.67 \mathrm{aB}$ & $14.33 \mathrm{bA}$ & $26.67 \mathrm{aA}$ & $21.44 a B$ & $12.26 \mathrm{aA}$ & $10.64 a A$ & $22.90 a$ \\
\hline Cuba 116 & $14.78 \mathrm{aA}$ & $17.00 \mathrm{bA}$ & $21.06 \mathrm{bA}$ & $21.33 a A$ & 13.33aA & $16.15 \mathrm{aA}$ & $29.48 a$ \\
\hline Mercker & $15.67 a A$ & $16.33 \mathrm{bA}$ & $15.56 \mathrm{dA}$ & $15.39 \mathrm{bA}$ & 16.86aA & 20.31aA & $37.18 a$ \\
\hline Cameroon & $15.22 \mathrm{aA}$ & $17.33 \mathrm{bA}$ & $21.44 \mathrm{bA}$ & $9.56 \mathrm{bB}$ & 18.38aA & 13.47aA & $31.85 a$ \\
\hline Piracicaba 241 & 13.78aA & $17.00 \mathrm{bA}$ & $13.44 \mathrm{dA}$ & $16.17 \mathrm{bA}$ & 14.37aA & 13.62aA & $27.99 a$ \\
\hline Vrukwona & 14.33aA & $16.00 \mathrm{bA}$ & $18.50 \mathrm{cA}$ & $12.44 \mathrm{bB}$ & 16.00aA & 16.38aA & $32.38 a$ \\
\hline Napier & $12.89 \mathrm{aB}$ & $17.00 \mathrm{bA}$ & $21.39 \mathrm{bA}$ & $13.50 \mathrm{bB}$ & 14.63aA & $12.15 \mathrm{aA}$ & $26.79 a$ \\
\hline Porto Rico & 11.78aB & $17.67 \mathrm{bA}$ & $25.22 \mathrm{aA}$ & $25.28 \mathrm{aA}$ & 11.97aA & 16.73aA & $28.71 a$ \\
\hline Gua & $12.78 \mathrm{aA}$ & $15.67 \mathrm{bA}$ & $18.94 \mathrm{cA}$ & $13.44 \mathrm{bB}$ & 13.13aA & $15.58 \mathrm{aA}$ & $28.71 a$ \\
\hline Cubano Pinda & $12.56 \mathrm{aB}$ & $20.33 a A$ & $18.56 \mathrm{cA}$ & $12.39 \mathrm{bB}$ & 12.27aA & 16.48aA & $28.75 a$ \\
\hline BRS Canará & 13.67aA & $16.00 \mathrm{bA}$ & $17.39 \mathrm{cA}$ & $13.56 \mathrm{bA}$ & 16.79aA & 19.69aA & $37.18 a$ \\
\hline$\overline{C V}(\mathrm{a})(\%)$ & 15.07 & & 27.06 & & 30.21 & & 26.89 \\
\hline CV (b) (\%) & 12.76 & & 13.69 & & 28.50 & & 16.33 \\
\hline
\end{tabular}

wall. Thus, the reduction in the volatile fractions of the biomass as the hemicellulose, polysaccharides of lesser relevance in the composition of the oxidizer compared to the other fibrous fractions such as lignin and cellulose, due to the low thermal stability and the lower activation energy in the direct combustion. In addition, its presence increases ash generation during combustion $[29,30]$.

When comparing the two seasons in the first year, the genotypes had no difference $(P>.05)$, excepting CNPGL 91-25-1 and Piracicaba 241 which showed a reduction in the SD during the rainy season $(P<.05)$ with values of 15.08 and $13.30 \mathrm{~mm}$, inversely to Cuba 116 in the dry season $(P<.05)$ with $13.0 \mathrm{~mm}$ (Table 4$)$. In the dry season, the CNPGL 93-41-1, Piracicaba 241, CNPGL 91-25-1 and Mercker genotypes, were highlighted with higher $S D(P<.05)$. In the rainy season, only Cubano Pinda presented the largest SD $(P<.05)$ with $20.58 \mathrm{~mm}$.

In the second year of cultivation, comparing both seasons, it is verified that in the rainy season there was a greater SD $(P<.05)$ to the CNPGL 93-41-1, CNPGL 91-25-1, Taiwan A 25, Napier, Porto Rico and Cubano Pinda genotypes (Table $5)$. In the rainy season, the CNPGL 93-41-1, CNPGL 91-25-1 and Cubano Pinda genotypes had the largest SD. There was no difference $(P<$ .05) between the genotypes during the dry season and the mean was $13.61 \mathrm{~mm}$.
The tillering is a characteristic of high heritability and interest in breeding programs, since the possibility of crossing [31], because it can contribute to obtain genotypes with higher dry matter yield [21]. When comparing both seasons in the first year of cultivation, there was no significant difference between the genotypes (Table 4). The Taiwan A 25 and Porto Rico genotypes had higher TN in the dry season $(P<$ $.05)$, with 22.94 and 26.72 tiller linear $\mathrm{m}^{-1}$, respectively.

In the rainy season, there was no statistical difference between genotypes with a mean of 16.17 tiller linear $\mathrm{m}^{-1}$. [32] observed higher TN, evaluating 80 elephant grass genotypes at different times. These authors contacted that TN varied between 22 and 91 for the genotypes Cana D'África and BAG-92, respectively, in the dry season, and from 26.1 to 72.6 tiller linear $\mathrm{m}^{-1}$ to genotypes Goiano and EMPASC 309 respectively, in the rainy season.

In the second year of cultivation, when comparing both seasons, the Taiwan A 25, Cameroon, Vrukwona, Napier, Guaçu and Cubano Pinda genotypes obtained higher TN ( $P$ $<.05$ ) in the dry season (Table 5). In the dry season, the best genotypes were Taiwan A 25 and Porto Rico with TN of 26.67 and 25.22, respectively. In the rainy season, the genotypes that presented higher NT $(P<.05)$ were CNPGL91-25-1, Taiwan A25, Cuba 116 and 
Porto Rico with values ranging from 25.88 to 18.94 tiller linear $\mathrm{m}^{-1}$.

However, it does not mean that genotypes that produce a high number of tillers will result in high dry matter yield for energy production via direct combustion. This variable is most useful to predict the potential of dry matter production [33]. According to [34], there are two canonical pairs with distinct slopes in the elephant grass, that is, when the plant grows more, it becomes smaller and with a smaller diameter. This results in plants with low fiber content and high nitrogen content culminating in low calorific power. Another aspect is that when the plant has less, its stems are more robust and the plants are higher, with high fiber contents, low nitrogen content and consequently high calorific value.

Comparing dry matter yield in the first year of cultivation between both seasons (Table 4), observed lower DMY to Cuba 116, Porto Rico and Cubano Pinda genotypes in the dry season. This may be a problem and indicate that these genotypes have low genotypic stability over the two seasons. In addition, they can interfere in the planning of the activities of a company that produces ecological firewood that will have a reduction in the production during the dry period.

During the dry season, there was no difference between the genotypes and the mean DMY was 20.38 ton $\mathrm{DM} \mathrm{ha} \mathrm{h}^{-1}$. Otherwise, in the rainy season, the genotypes that obtained the highest DMY $(P<.05)$ were CNPGL 91-25-1, Cuba 116, Mercker, Porto Rico, Cubano Pinda and BRS Canará. It can be noticed that only in the rainy harvest, these genotypes showed yield above 30 ton DM ha ${ }^{-1}$ harvest $^{-1}$, that is, values above the yield obtained by eucalyptus (20 ton DM ha ${ }^{-1}$ year $\left.^{-1}\right)$.

Regarding annual dry matter yield in the first year of cultivation (Table 4), there are promising genotypes with yield above 50 ton DM ha ${ }^{-1}$ year $^{-9}$. The BRS Canará, Porto Rico, Mercker, CNPGL 91-25-1 and Cubano Pinda genotypes were the ones that stood out the most with ADMY ranging from 52.15 to 59.58 ton DM ha ${ }^{-1}$ year $^{-1}$. Regarding to BRS Canará genotype, this was launched in 2012 by Embrapa to be used in the form of grass, with the harvest and supply in the form of forage to the animals, but we can see the double suitability of this genotype and can also be used for bioenergy production.

Genotype yield demonstrates why elephant grass stands out among energy crops [35], and with total possibility of insertion into the Brazilian energy matrix consolidated by the use of sugarcane and eucalyptus, mainly by the amount of biomass produced and the production cycle [2]. [12], evaluating elephant grass cultivars in the Northeast region of Brazil, observed that BRS Canará and Cubano Pinda obtained ADMY ranging from 66.3 to 84.3 ton DM ha ${ }^{-1}$ year $^{-1}$ at 6 months of cultivation.

In the second year of cultivation (Table 5), there was no difference $(P>.05)$ to seasons and genotypes within each season, with mean DMY of 14.94 ton DM ha ${ }^{-1}$ and mean ADMY of 29.94 ton DM ha ${ }^{-1}$ year ${ }^{-1}$, that is, it occurred a $39.17 \%$ and $39.05 \%$ reduction, respectively. Nevertheless, it was verified that all the genotypes had dry matter yield higher than that obtained by eucalyptus ( 20 ton DM ha ${ }^{-1}$ year $^{-1}$ ).

The reduction in dry matter yield per season and annual obtained in the second year of cultivation was due to reduction of soil fertility and not replacement of nutrients through fertilization, since after the last harvest, the reduction in nutrient contents $\mathrm{P}, \mathrm{K}$ and $\mathrm{OM}$ (Table 2). A similar occurrence was verified by $\mathrm{Ra}$ et al. [36], because the mean DMY of eight elephant grass genotypes was 17.5 ton DM ha ${ }^{-1}$ year $^{-1}(2012$ and 2013), but decreased 6.4 ton DMM ha ${ }^{-1}$ (2013 and 2014), which was expected due to the reduction of natural soil fertility.

Elephant grass is naturally a grassland with high productive potential, either to animal feed or to energetic purposes, but the crop presents high extraction of nutrients from the soil, such as $\mathrm{N}, \mathrm{K}$, $\mathrm{Ca}$ and S, [37]. According Santos et al. [38], evaluating the nutrient removal in elephant grass pasture, observed that the yield of 30 ton DM $\mathrm{ha}^{-1}$ year ${ }^{-1}$ provides extraction equivalent to 480 $\mathrm{kg} \mathrm{N} \mathrm{ha}^{-1}$ year $^{-1}, 361 \mathrm{~kg} \mathrm{~K}_{2} \mathrm{O}$ ha year ${ }^{-1}$ and 117 kg $\mathrm{P}_{2} \mathrm{O}_{5}$ ha $^{-1}$ year ${ }^{-1}$. [39], evaluating elephant grass genotypes for energy production in the form of biomass, verified that the most extracted nutrients of the soil were potassium (310 kg ha $\left.{ }^{-1}\right)$, calcium (167 kg ha-1), nitrogen $\left(121 \mathrm{~kg} \mathrm{ha}^{-1}\right)$, magnesium $\left(79 \mathrm{~kg} \mathrm{ha}{ }^{-1}\right)$ and phosphorus $\left(41.4 \mathrm{~kg} \mathrm{ha}^{-1}\right)$, which are essential to better exploit the productive potential of the crop [40].

Thus, the economic exploitation of elephant grass for bioenergy production via direct combustion special attention should be given to the replacement of nutrients, in order to maintain or even increase the dry matter yield obtained in 
the first year, in the following years that are want to produce.

\section{CONCLUSION}

Elephant grass is an excellent alternative for energy purposes mainly due to high percentage of stem and dry matter yield, but maintenance of soil fertility is necessary to obtain satisfactory yields. According to the agronomic characteristics, the promising genotypes for direct burning are CNPGL 91-25-1, Cubano Pinda, BRS Canará, Porto Rico and Mercker.

\section{ACKNOWLEDGEMENTS}

We are grateful to the Coordination of Research of People of Superior Level (CAPES), Federal University of Mato Grosso.

\section{COMPETING INTERESTS}

Authors have declared that no competing interests exist.

\section{REFERENCES}

1. Saidur $R$, Abdelaziz EA, Demirbas A, Hossain MS, Mekhilef $S$. A review on biomass as a fuel for boilers. Renewable and Sustainable Energy Reviews. 2011; 15(5).

2. Fontoura CF, Brandão LE, Gomes LL. Elephant grass biorefineries: Towards a cleaner Brazilian energy matrix? Journal of Cleaner Production. 2015;96:85-93.

3. Souza MCO, Corazza RI. From Kyoto protocol to Paris agreement: An analysis of global climate regime changes based on a study of the evolution of green gases emissions profiles. Desenvolvimento Meio Ambiente. 2017;42:52-80. Portuguese

4. Reis MC, Sabrinho SF, Ramalho MAP, Ferreira DF, Ledo FJS, Pereira AV. Allohexaploid pearl millet $x$ elephantgrass population potentential for a recurrente selection program. Pesquisa Agropecuária Brasileira. 2008;43(2):195-199.

5. Chakraborty S, Aggarwal V, Mukherjee D, Andras K. Biomass to biofuel: A review on production technology. Asian Journal of Chemical Engineering. 2012;7:254-262.

6. Madakadze C, Masamvu TM, Radiotis T, Li J, Smith DL. Evaluation of pulp and paper making characteristics of elephant grass (Pennisetum purpureum Schum) and switchgrass (Panicum virgatum L.). African Journal Environment Science and Technology. 2010;4:465-470.

7. Santos CC, Souza W, Sant'anna C, Brienzo M. Elephant grass leaves have lower recalcitrance to acid pretreatment than stems, with higher potential for ethanol production. Industrial. Crops \& Products. 2018;111:193-200.

8. Mohammed IY, Abakr YA, Kazi FK, Yusup S, Alshareef I, Chin SA. Comprehensive Characterization of Napier Grass as a Feedstock for Thermochemical Conversion. Energies. 2015;8:3403-3417.

DOI: $10.3390 /$ en8053403

9. Morais RF, Quesada DM, Reis VM, Urquiaga S, Alves BJR, Boddey RM. Contribution of biological nitrogen fixation to elephant grass (Pennisetum purpureum Schum.). Plant and Soil. 2011;349:1-12.

10. Liu S, Abrahamson LP, Scott GM. Biorefinery: Ensuring biomass as a sustainable renewable source of chemicals, materials, and energy. Biomass Bioenergy. 2012;39:1-4.

11. Samson R, Mani S, Boddey R, Sokhansanj S, Quesada D, Urquiaga S, Reis V, Ho Lem C. Perennial grasses for developing a global bioheat industry, CRC Critical Reviews. Plant Science. 2005;24: $461 \mathrm{e} 495$.

Available:http://dx.doi.org/10.1080/073526 80500316508

12. Marafon AC, Santiago AD, Camara TM, Rangel JHA, Amaral AFC, Lêdo FJS, Bierhals AN, Paiva HL. Production potential and quality of elephantgrass biomass for energy purposes. Aracaju: Embrapa Tabuleiros Costeiros. 2014;6. (Technical Circular) Portuguese

13. Quirino WF, Vale AT, Andrade APA, Abreu VLS, Azevedo ACS. Calorific power of wood, materials, and ligno-cellulosic materials. Revista da Madeira. 2005;89: 100-106.

14. Seguchi HJM, Vicente NG, Mazzarella VNG, Ferreira PH, Katayama MT. Cost of production of elephant grass and eucalyptus compacted in bripells and briquets, using solar and induced drying. Revista Brasileira de Energias Renováveis. 2017;6(2):228-244. Portuguese

15. Pereira AV, Lédo FJS, Machado JC, Kurumi BRS, Capiaçu BRS. New elephant grass cultivars for grazing and cut-andcarry system. Crop Breeding and Applied Biotechnology. 2017;17:59-62. 
16. Marafon AC, Santiago AD, Machado JC, Guimarães VS, Paiva HL. Biomass production in tropical grasses with energy potential. Aracaju: Embrapa Tabuleiros Costeiros. (Research and Development Bulletin, 132). Portuguese. 2017;19.

17. Rocha JRASC, Machado JC, Carneiro PCS, Carneiro JC, Resende MDV, Pereira AV, Carneiro JES. Elephant grass ecotypes for bioenergy production via direct combustion of biomass. Industrial Crops and Products. 2017;95:2732.

18. Ribeiro AC, Guimarães PTG, Alvarez $\mathrm{VVH}$. Recommendations for the use of correctives and fertilizers in Minas Gerais: $5^{\text {th }}$ Approach. Viçosa: Comissão de Fertilidade do Solo do Estado de Minas Gerais - CFSEMG; 1999. Portuguese

19. Banzato DA, Kronka SN. Agricultural Experimentation. 2. ed. Jaboticabal: FUNEP. 1992;247. Portuguese

20. Mota VJG, Reis ST, Sales ECJ, Rocha Júnior VR, Oliveira FG, Walker SF, Martins CE, Cóser AC. Irrigation slides and nitrogen rates on elephant grass pasture in the dry season of the year in northern Minas Gerais. Brazilian Journal of Animal Science. 2010;39(6):1191-1199.

21. Menezes BRS, Daher RF, Gravina G de, Amaral Júnior AT, Oliveira AV, Schneider LA, Silva VB. Correlations and trail analysis in elephant grass for energy purposes. Brazilian Journal of Agricultural Sciences. 2014;9(3):465-470. Portuguese

22. Paciulo DSC, Gomide JA, Ribeiro KG. Nitrogen fertilization of elephant grass cV. Mott. 1. Forage yield and morphophysiological characteristics when reaching 80 and $120 \mathrm{~cm}$ in height. Brazilian Journal of Animal Science. 1998;27(6):1069-1075.

23. Obernberger I, Brunner T, Barnthaler G. Chemical properties of solid biofuels significance and impact. Biomass \& Bioenergy. 2006;30:973-82.

24. Ferreira EA, Abreu JG, Martinez JC, Braz TGS, Ferreira DP. Cutting ages of elephant grass for chopped hay production. Pesquisa. Agropecuária Tropical. 2018;48(3):245-253. Portuguese

25. Garcia DP, Caraschi JC, Ventorim G, Viera FHA, Protásio TP. Comparative energy properties of torrefied pellets in relation to pine and elephant grass a pellets. Bioresources. 2018;13(2):2898-2906.

26. Oliveira LF, Daher RF, Menezes BRS, Vivas M, Rocha AS, Ponciano NJ, Junior
ATA, Arauo MSB, Pereira TNS, Silva VB. Genetic diversity of elephant grass (Cenchrus purpureus [Schumach.] Morrone) for energetic production based on quantitative and multi-category traits. Chilean Journal of Agricultural Research. 2017;77(1).

27. Quesada DM, Boddey RM, Reis VM, Urquiaga S. Qualitative parameters elephant grass genotypes (Pennisetum purpureum Schum.) studied for the production of energy from biomass. Embrapa: Seropédia; 2004. (Technical Circular 8). Portuguese

28. Silva VB, Daher RF, Menezes BS, Gravina GA, Araújo MSB, Junior ARC, Cruz DP, Almeida BO, Tardin D. Selection among and within full-sib families of elephant grass for energy purposes. Crop Breeding and Applied Biotechnology. 2018;18:8996.

29. Oliveira LF, Daher RF, Menezes BRS, Vivas $M$, Rocha AS, Ponciano NJ, Junior ATA, Arauo MSB, Pereira TNS, Silva VB. Genetic diversity of elephant grass (Cenchrus purpureus [Schumach.] Morrone) for energetic production based on quantitative and multi-category traits. Chilean Journal of Agricultural Research. 2017;77(1).

30. Chen Z, Hu M, Zhu X, Guo D, Liu S, Hu Z, Xiao B, Wang J, Laghari M. Characteristics and kinetic study on pyrolysis of five lignocellulosic biomass via thermogravimetric analysis. Bioresource Technology. 2015;192:441-50.

31. Van De Velden M, Baeyens J, Brems A, Janssens B, Dewil R. Fundamentals, kinetics and endothermicity of the biomass pyrolysis reaction. Renewable Energy. 2015;35(1):232-242.

32. Silva VQR, Daher RF, Gravina GA, Lédo FJ, Tardin FD, Souza MC. Combinatory capacity of elephant grass based on morphoagronomic characters. Animal Industry Bulletin. 2014;71(1):63-70.

33. Scheneider LSA, Daher RF, Menezes BRS, Freitas RS, Sousa LB. Selection of elephant grass genotypes for forage production. Journal of Agricultural Science. 2018;10(12):42-52.

34. Daher RF, Pereira AV, Pereira MG, Lédo FJS, Amaral Junior AT, Rocabado JMA, Ferreira CF, Tardin FD. Forage trait analysis of elephant grass (Pennisetum purpureum Schum.). Rural Science. Santa Maria. 2004;34:1531-1535. 
35. Rossi DA, Menezes BRS, Daher RF, Gravina GA, Lima RS, Ledó FJS, Gottardo RD, Campostrini E, Souza CLM. Canonical correlations in elephant grass for energy purposes. African Journal of Biotechnology. 2014;13(31).

Available:http://dx.doi.org/10.5897/AJB201 4.13915

36. Ra K, Shiotsu F, Abe J, Morita S. Biomass yield and nitrogen use efficiency of cellulosic energy crops for ethanol production. Biomass \& Bioenergy. 2012; 37:330-334.

37. Rueda JA, Ortega-Jimenez E, HenándezGaray A, Enríque-Quiroz JF, GuerreroRodríguez JD, Quero-Carrilo AR. Growth, yield, fiber content and lodging resistance in eight varieties of Q4 Cenchrus purpureus (Schumach.) Morrone intended as energy crop. Biomass and Bioenergy. 2016;1-7.

38. Santos RL, Azevedo VM, Freire FJ, Rocha AL, Tavares JA, Freire MBGS. Extraction and efficiency of nutrient use in elephant grass in the presence of gypsum. Brazilian Journal of Soil Science. 2012;36(2):497505.

Available:https://doi.org/10.1590/S010006832012000200019 Portuguese

39. Carvalho MM, Alvim MJ, Xavier DF. Elephant grass: Production and use. Juiz de Fora: EMBRAPA-Gado de Leite. 1997; 259. Portuguese

40. Quesada DM. Quantitative and qualitative parameters of different elephant grass genotypes as potential for energy use. Thesis, Universidade Federal Rural do Rio de Janeiro, Seropédica-RJ. 2005;76.

(c) 2019 Favare et al.; This is an Open Access article distributed under the terms of the Creative Commons Attribution License (http://creativecommons.org/licenses/by/4.0), which permits unrestricted use, distribution, and reproduction in any medium, provided the original work is properly cited.

Peer-review history:

The peer review history for this paper can be accessed here: http://www.sdiarticle3.com/review-history/49640 